\title{
The Curious Treatment of Capitalism in Legal Education
}

\author{
George L. Priest
}

Published online: 30 March 2012

(C) Springer Science + Business Media, LLC 2012

The function of law schools is to teach the legal foundations of order in the society, which means necessarily the foundations of the capitalist order of our society. Strangely, however, in the history and development of legal teaching, there has been little specific attention to capitalism as an institution.

There are both historical and practical reasons for this lack of attention. The development of a legal system long preceded the formal study of law. English common law which dates from the 14th or 15th Centuries was expressly adopted after the Revolution by the newly-formed American states. The first law schools in the U.S. began a century later, in the mid-19th Century, and became seriously professional only in the early-20th Century. It is an interesting question (though not pursued here) at what point in the rise of complexity of an institution such as the law, schools develop to train persons interested in the field to understand their practice at a more abstract level. This happened in England some centuries after the development of a legal system. In the U.S., prior to the development of law schools and for roughly 75 years after the founding of the first rudimentary law schools, training in the law occurred almost entirely through apprenticeship in the offices of practitioners. Occupied by their basic calling, practitioners did not focus on the broader understanding of the role of law in the ordering of society, and capitalism considered as an institution was not an element of legal training.

Even after law schools became established in the U.S., legal education was not immediately theoretical. Legal training served to organize and systematize the increasing corpus of legal rules but, essentially, took the legal system as it was,

G. L. Priest $(\bowtie)$

Yale Law School,

P.O. Box 208215, New Haven, CT 06520, USA

e-mail: george.priest@yale.edu and did not analyze it critically nor analyze the legal organization of the society in relation to alternative forms of social organization.

Beginning in the late-19th Century, there were battles within the legal and practitioner academy over methods of systematization of the law. In retrospect, these battles resemble debates between social engineering and market transactions as mechanisms for organizing social order. But these disputes were not recognized at this theoretical level within law schools.

Battles within the academy affecting the understanding of capitalism became more pointed as political pressures rose in the late 19th Century and early 20th Century over the legality of advancing forms of government regulation, such as the regulation of working hours of women and children. Below the surface, these were battles over governmental constraints on the operation of capitalism. As mentioned, capitalism requires a legal foundation. The question in these debates was what was to be the content of that legal foundation.

An important turning point in this debate was the Great Depression of the 1930s. The Depression, and the failure to understand its sources, led in the U.S. to great political pressure for increased governmental regulation of most economic activities in the society. It led to a modification of many, though not all, of the previously-established foundations of the capitalist order.

After some years, however, the New Deal advance plus the accompanying - though not totally convincing-theoretical justification of increased governmental control of the economy generated a counter reaction, chiefly employing economic analysis to challenge greater governmental control. Here, the achievements of capitalism as an institution were more generally acknowledged.

Deriving from this work, in the late-1960s and 1970s, the economic approach to the understanding of law and legal 
institutions became dominant. There occurred a great shift in thinking about the law, from a categorical or weak philosophical approach to the operation of the legal system to an openly functional approach to law. According to this view, the most important questions became, what are the effects on the society of legal rules in general, as well as of one rule versus another? How can the law generally or individual legal rules specifically be redefined to increase the welfare of the society?

This transformation of analysis, still, does not quite address capitalism as a method of social organization. But it is coming closer. An important contribution to this approach was the work of Richard A. Posner with his important book Economic Analysis of Law, whose first edition was published in 1972. The book remains highly influential; its 10th edition was published in 2010. Posner claimed in the book that the legal rules of the common law, though individually issued by different judges over many centuries, all achieved economic efficiency. He, with his gifted co-author William Landes, wrote possibly 75 other articles purportedly supporting the proposition. Posner's book, along with the work of my colleague Guido Calabresi, created a new field, law and economics, that had an important effect in redirecting legal analysis toward a functional understanding of the role of law in the society. Again, according to this approach, legal rules and institutions were to be analyzed according to their economic effects on societal production.

Even here, the greater application of economic analysis to the law did not constitute the study of capitalism. As shall be explained, Posner's approach is, in fact, a form of refined social engineering: judges, in contrast (but only in title) to governmental regulators, choose the economically ideal rules for society. There is no attention to capitalism as an institution. Indeed, in an important sense, in the Posnerian world, markets have no role in defining or correcting the legal order. The determinants of economic growth are not considered.

There is reason to believe that this limited scope of economic analysis may change in the future. But, today, the careful study of capitalism as an institution or even as a mechanism for advancing societal interests is hardly addressed in legal education.

\section{The Legal Foundations of the Market Order}

Modern legal education aspires to teach students the principles and underlying doctrines of each of the basic fields of law. As a consequence, by necessity, modern legal education teaches students the basic doctrines underlying and establishing the contours of our market economy.

In every law school in the country, in a Property course, students are required to learn the basic legal principles defining private property; in a Contracts course, the basic legal principles underlying market transactions; in Torts and Criminal Law courses, the legal principles of those areas of law protecting property and contract. In most law schools, these basic courses comprise the first semester or, more typically, the entire first year of the law school curriculum.

In the second and third years of law school, students take advanced courses that again address the organizing principles of a market economy. In a Corporations course, a student will study the legal rules controlling corporate organization; in a Securities Law course, the legal rules defining how corporations are allowed to raise capital; in Commercial Law courses, more advanced forms of contracting, including the rules controlling the sale of goods and security for loans; in an Antitrust course, the legal rules controlling the competitive actions of corporations.

In addition to these courses directly addressing the legal rules controlling economic activity, most law schools provide courses giving attention to the control of governmental activity in a variety of Constitutional Law courses. In many of these courses, there is substantial attention to the constitutional provisions constraining the extent of governmental control of the economy or, more realistically, how those constitutional constraints have been relaxed over the past 80 years. Other public law courses address less central, but still important features of the law controlling market operations, such as Antidiscrimination Law.

There are some courses that deal with legal issues somewhat more remote from the capitalist order. In the U.S., most law schools offer courses dealing with First Amendment Law and Election Law, but even these courses have some relation to the organization of society, because it is widely believed, though on little theoretical or empirical support, that societies that establish greater political freedom have more robust competitive orders.

In my experience, though most of these courses deal in some way with the foundations of our capitalist order, none focuses upon capitalism as an institution. As mentioned, there are both practical and historical reasons for this lapse. As a practical matter, law schools exist to train lawyerspractitioners of the law-whose careers will consist of administering a complex legal system, not engaging in discussions of political or economic philosophy, except on their own time. Because of this focus, most of legal education throughout its history has consisted of teaching by categorical analogy: Does this new dispute more resemble this precedent or that? Are there legal grounds for distinguishing the outcome of this case from that? Some small number of elite schools attempt to differentiate themselves as more theoretical than practical. But theory here chiefly means broader versus narrower generalizations of the defining principles of existing law. 


\section{Early Legal Battles Involving Capitalism}

This is not to say that there have not been what might be called mini-battles as between capitalism and socialism in the legal world. In the late-19th Century, efforts were made to supplant the aggregated rules of the common law (consisting of decisions by individual judges) with legislatively-enacted codes of law, on the model of the French Napoleonic Codes of the late18th Century. The Napoleonic Code model was expressly contrasted to English common law and defended as more rational because centrally commanded. In the U.S., there was substantial support for the adoption of law codes, successful in Louisiana, a former French colony that remains a code state today, and by legal giants such as David Dudley Field, whose advocacy of codes that he had written had some success, chiefly in new states in the West. For example, much of California private law today derives from the Field codes.

The underlying context of the codification movement implicated capitalism. The codification movement of the late-19th and early-20th Centuries generated resistance - generally, a conservative resistance - based upon the belief that the organic evolution of law through the common law method was superior to governmental direction through legislative, which is to say political, codification. Proponents of codification had supported the cause by arguing that common law decisions, issued each by a different judge in different legal communities, were incoherent - central authority was needed to clarify and systematize the law to clear up the confusion.

The conservative response to this claim was not quite based on the superiority of market to government control, but it did promote the virtues of spontaneous ordering through the common law, principally by devoting enormous effort to show that the aggregated rules of the common law could be systematized and coherently explained. An institution was founded to promote this end, the American Law Institute, appointing prominent lawyers and academics as members, whose principal function was and still is to create what are called Restatements of Law. Restatements are collections of the various rules of different areas of common law attempting to show that the organic development of individual cases in the various U.S. jurisdictions does not lead to incoherence, but to a set of basic legal principles that are largely similar across the jurisdictions.

The battle between legislative codification as social engineering and organic development through the common law continues today. The codification movement achieved perhaps its greatest success with the nearly nationwide adoption in the 1950s and 1960s of the Uniform Commercial Code, codifying the law regarding the sale of goods and secured transactions. ${ }^{1}$ The codification movement retains a modern

\footnotetext{
${ }^{1}$ The only state that refused to adopt the Uniform Commercial Code was Louisiana which had in place its own commercial code derived, as mentioned, from the Napoleonic codes.
}

currency. An institution, the National Conference of Commissioners on Uniform State Laws, with representatives from the 50 states, meets regularly and drafts statutes that it recommends to state legislatures with the ambition of unifying law across the country. Some of these statutes are enacted; most are not. Today, the principal justification for the adoption of these codes is not socialism, but achieving legal uniformity across the states.

Interestingly, although what was once a debate as between governmental dictation versus spontaneous organic development of law, the debate is not framed today in terms of governmental regulation versus capitalism. Today, the conceptually contrasting efforts of codification by the National Conference of Commissioners on Uniform State Laws and the protection of the common law method by the Restatements of the American Law Institute are not generally viewed as competing, but as complementary. The initial conflict between government regulation and spontaneous organization has been overcome by the arcania of a complex legal system. All law school curricula have courses devoted to codified law as well as courses in which students are encouraged to refer to Restatements of the common law. But the emphasis in both is systematization of a wide range of legal rules: issues of governmental control versus capitalism are entirely absent.

An important legal development occurred in the late 19th and 20th Centuries with the creation of what is now known as the substantive due process school of the Supreme Court. In a substantial number of opinions, the Supreme Court struck down various state legislative statutes controlling matters such as maximum hours of work, especially for women and children, as well as other regulations on contracting, on the grounds that these legislative restrictions impaired the important societal values of the right to control private property and the right to enter voluntary contracts. ${ }^{2}$ The extent to which this legal approach affected legal education is not evident, and has not been clearly defined. It remains something less than a support for capitalism as an institution.

\section{The Great Depression and the Rise of Government Regulation}

The Great Depression of the 1930s generated a seismic change in the level of government regulation of the capitalist order. As with the so-called Great Recession of today (20082011, to date), the causes of the Great Depression of the 1930s were not immediately understood. An initial and broadly held conclusion was that the capitalist order had failed, confirming the predictions of Marx and his followers, including the

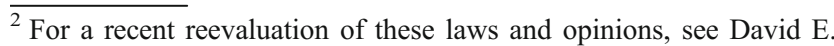
Bernstein, Rehabilitating Lochner: Defending Individual Rights against Progressive Reform (2011).
} 
popular American Thorstein Veblen, that capitalism - because of the accelerating exploitation of workers by owners of capital — would generate increasingly intense economic crises which could only be solved by greater popular (in the case of Marx, worker) control over the means of production and an accompanying redistribution of wealth.

It is now widely understood that the Great Depression resulted from both the bursting of an equities bubble (similar to the bursting of the real estate bubble leading to the Great Recession today) and from policies of the world's central banks that magnified the effect by drastically reducing the money supply (unlike today) as governments competed over gold reserves, where gold was the standard securing each government's currency. Today, most, though not all, economists attribute the severity of the Great Depression of the 1930s to government policies, not to the failure of capitalism.

In the political arena at the time, however, the popular understanding was different. In the U.S., substantial support developed for advanced forms of government regulation. Put briefly, it led to the overturning of the set of Constitutional doctrines - the substantive due process school - that, as mentioned, had protected rights of private property and rights of free contracting in favor of the endorsement of the authority of government to control the definition of property rights and of the right to contract through broader economic regulation.

The U.S. Supreme Court initially resisted these political changes. But following Franklin Roosevelt's attempt to pack (enlarge) the Supreme Court, a key Justice of the Court changed his view about the Constitutional protection of private property and contract ("the switch in time that saved nine"). Thereafter, the authority of state and federal governments to regulate economic activity advanced. The movement accelerated as Roosevelt subsequently was able to appoint to the Court individuals committed to the same goals.

I have not studied the reaction to these changes in all law schools - a subject worthy of study. At Yale Law School, greater government authority was endorsed broadly. Indeed, many Yale Law School faculty members left to assume important roles in the Roosevelt Administration. The endorsement of greater governmental regulation is likely to have been common to many law schools. The great extension of both state and government control over the economy enhanced the role of lawyers (as has the continued growth of government since the 1930s): there were new laws to write and, more importantly, new laws to interpret, both by regulators and the regulated, as new statutes had to be applied to the complex activities of our modern economy.

\section{The Pro-Capitalism Response}

To my knowledge, there was little opposition in law schools to the New Deal's advance of government regulation in the years following the Second New Deal and World War II. The War surely must have quieted opposition to increased government activity.

Following the War, however, a movement supporting capitalism began in opposition to the growth of government regulation that had occurred not only in the U.S., but worldwide. ${ }^{3}$ Hayek published The Road to Serfdom in 1944. He founded the Mont Pelerin Society in 1946. Following themes of The Road to Serfdom, the Mont Pelerin Society was dedicated (and to some extent still is) to the proposition that political interference with market activities is harmful: to freedom, though the Society was not overtly libertarian; and to broader individual and societal goals. The Society views itself as a bulwark of capitalism.

Among the founding members of the Mont Pelerin Society, there were no American legal academics; most were prominent economists: besides Hayek, Milton Friedman, Frank Knight, von Mises, Karl Popper, Michael Polyani, Lionel Robbins, and George Stigler, among others. One of the founding members, Aaron Director, a somewhat economist, would later be appointed to the University of Chicago Law School faculty, and play an important role in the support of capitalism in the legal academy. An equally important supporter of capitalism was Ronald Coase, not present at the first meeting of the Society but a member two years later, in 1948; later, a Life Member. Director and Coase would significantly affect the defense of capitalism against state regulation in legal education in later years.

Director is famously noted for his unwillingness to write articles himself, but for what proved to be an extraordinarily effective strategy of giving his ideas to others for them to publish. In 1958, many years after the founding of the Mont Pelerin Society (Director's activities during the intervening years are not well documented), after his appointment to the University of Chicago Law School faculty, he inaugurated The Journal of Law \& Economics. Coase succeeded him as Editor of the Journal in 1964. Director and Coase shared a deeply held belief that market activities were always superior to political interference in the market.

The early volumes of the Journal of Law \& Economics illustrate the belief in the superiority of the market to politics. The Journal announced itself as directed to the application of economic analysis to legal issues, but at its inception was devoted - as no law school journal has since been - to the promotion of the capitalist order. The first issues contain some articles that might be regarded as economic science, but contain numerous articles that are essentially essays in political economy — market oriented, pro-capitalism, political economy.

\footnotetext{
${ }^{3}$ Much of the discussion below is adapted from previous writings: Priest, "'The Limits of Antitrust" and the Chicago School Tradition', 6 J. Competition Law \& Econ. 1 (2010); Priest, 'Michael Trebilcock and the Past and Future of Law and Economics', 60 U. Toronto L. J. 155 (2010).
} 
These essays represent the closest legal scholarship has come to the support of capitalism as an institution. For example, Volume 2 of the Journal contains Hirschleifer's articles: "Capitalist Ethics-Tough or Soft"4 and "The Sumptuary Manifesto", and Buchanan's, "Positive Economics, Welfare Economics, and Political Economy"6; Volume 4 contains Stigler's, "Private Vice and Public Virtue". 7 Though these early volumes of the Journal do not ignore the scientific application of economic analysis, they resemble more closely a high-level journal of pro-capitalism political philosophy, than a journal of economic science.

The articles discussing political philosophy, however, were joined with articles presenting empirical work challenging the belief that governmental regulation enhanced societal welfare. From the earliest issues, the editorsDirector and Coase - encouraged articles critical of specific governmental interventions in the market, first, to complement, later, to completely supplant the essays on political economy. Antitrust law and economic regulation were particular subjects of criticism, ${ }^{8}$ though articles in the Journal also addressed the effects, economic and otherwise, of the minimum wage, ${ }^{9}$ unionization, ${ }^{10}$ licensing, ${ }^{11}$ and even the British National Health Service, ${ }^{12}$ among others. The articles published in the Journal of Law \& Economics during these years represent the strongest affirmation of capitalism - as an organizing system — in the history of legal education.

Perhaps the deepest capitalist critique of governmental regulation and the greatest defense of the market order was published in The Journal of Law \& Economics under Director, authored by the scholar who would become his successor as Editor, Ronald H. Coase. Coase's article, "The Problem of Social Cost", ${ }^{13}$ is the most famous article in the

\footnotetext{
${ }^{4} 2$ J.Law \& Econ.114 (1959).

5 J. Law \& Econ. 120 (1959).

62 J. Law \& Econ. 124 (1959). Buchanan became a member of the Mont Pelerin Society somewhat later, in 1957; subsequently, a Life Member.

74 J.Law \& Econ. 1 (1961).

${ }^{8}$ See, e.g., John S. McGee, Predatory Price Cutting: The Standard Oil (N.J.) Case, 1 J. Law \& Econ. 137 (1958).

${ }^{9}$ Marshall R. Colberg, Minimum Wage Effects on Florida's Economic Development, 3 J.Law \& Econ. 106 (1960); Yale Brozen, Minimum Wage Rates and Household Workers, 5 J. Law \& Econ. 103 (1962).

${ }^{10}$ Many articles in the early volumes addressed the effects of unions. See, e.g., Albert Rees, Do Unions Cause Inflation? $2 \mathrm{~J}$. Law \& Econ. 84 (1959); Melvin Lurie, Government Regulation and Union Power, 3 J. Law \& Econ. 118 (1960). The entirety of Volume 6 was devoted to studies of unionization.

${ }^{11}$ Thomas J. Moore, The Purpose of Licensing, 4 J. Law \& Econ. 93 (1961).

${ }^{12}$ D.S. Lees, The Logic of the British National Health Service, $5 \mathrm{~J}$. Law \& Econ. 111 (1962) ("the N.H.S. [is] incompatible in important ways, ... with the basic assumptions of a free society").

13 J. Law \& Econ. 1 (1960).
}

Journal as well as in the history of law and economics. For many years, it has been the most heavily cited article both among articles in law journals and, separately, among articles in economics journals.

Many are surely familiar with the article, but the political dimension of Coase's analysis and how his article was meant to defend and promote the capitalist order are often unappreciated. The article is remembered today as vastly changing our understanding of the effects of legal rules. But it was not drafted with that ambition in mind and does not remotely pursue the implications for the effects of tort law or even more generally property law, though Coase's examples come from property law cases. That work was later accomplished by Harold Demsetz, Richard Posner, and others. Coase's article, instead, was directed at attacking the purported demonstration by the economist Arthur Pigou that government, including the courts, could and should intervene in multiple markets to correct what we now call externalities. ${ }^{14}$ The point of the article was to show that Pigou's analysis of correcting externalities was unsupportable; the market would control externalities in a fashion that no government could hope to equal.

The political dimension of the Coase Theorem and its relationship to capitalism is often ignored. To Coase, the implication of the proposition that "In the absence of transaction costs, the assignment of liability will have no effect on the allocation of resources" is that courts and the government can do no good by interfering in markets. It is an implication of the point that, if government action can somehow reduce transaction costs, it should do so. But the major point is that courts and the government are fooling themselves by attempting to improve upon market outcomes. The market will determine the allocation of resources regardless of anything the government or courts attempt to do. Coase's ambition was to deflate arguments for more intrusive government, not-as it happened-to revolutionize our understanding of the operation of the legal system. It is not often remembered that the academic project to which Coase turned after "The Problem of Social Cost" was not the extension of the Coase Theorem to the analysis of legal rules, but an attack on one of the last major institutional vestiges of socialism in Western societies, the post office. ${ }^{15}$ The Coase Theorem follows directly from a belief system that sees market transactionsthe heart of capitalism - as inherently superior to government interventions. Market transactions can serve to solve problems among conflicting property uses that governmental interventions cannot improve.

\footnotetext{
${ }^{14}$ A.C. Pigou, The Economics of Welfare (1920).

${ }^{15}$ Ronald H. Coase, The British Post Office and the Messenger Companies, 4 J. Law \& Econ. 12 (1961).
} 
The Rise of Law and Economics, Posner, and the Decline of the Defense of Capitalism

The Coase Theorem, challenging or, more accurately, redefining the circumstances under which legal rules will have effects, so upset conventional understandings of the law that it took many years of scholarly debate to understand its implications. The article can justly be attributed with inaugurating a new scholarly field, law and economics, which has become the dominant interdisciplinary field in legal education today.

Equally important to the establishment of the field of law and economics was the publication in 1972 of Richard A. Posner's Economic Analysis of Law. Posner's book claimed to show that the individual rules of the common law areas of torts, contracts, property, and so on, were defined to achieve economic efficiency. In the book, Posner distinguished public law subjects as not achieving efficiency, but controlled by political forces. This distinction seemed consistent with the Director-Coase criticism of government interference, though Posner provided no clear explanation for the reason for differences as between private and public law outcomes.

Posner's work had three principal effects important for the field of law and economics. First, it vastly expanded the scope of law and economics beyond antitrust and economic regulation, the focus of Director and Coase. Posner extended economic analysis to all fields of civil law and, ultimately, to the entire legal system. In this respect, the work of my colleague Guido Calabresi was also important. Calabresi, in a series of essays that later formed the core of his 1970 book, The Cost of Accidents, (preceding Posner) had applied a form of economic analysis to the field of accident law.

The second principal effect of Posner's work on the field was that its encyclopedic application of economic analysis to every area of law attracted - demanded-the attention of most serious scholars in the legal academy. The broad scale of Posner's analysis required most legal scholars to confront Posner's claims. This vastly increased the visibility and relevance of economic analysis. Even those rejecting Posner's claims were forced to acknowledge their existence. Calabresi aided this aspect of the growth of the field as well because he appointed his work, appropriately, as an alternative to Posner's single-focused theory of the efficiency-of-thelaw. Calabresi in The Cost of Accidents and in other articles claimed to show that the law endorsed valuesespecially redistributive values-beyond economic efficiency. Calabresi's embrace of multiple values provided a respite for many from Posner's relentless emphasis of efficiency, but Calabresi could never or never attempted to challenge Posner by claiming some coherent set of alternative values could explain the entire content of the law. ${ }^{16}$

The third and I believe most important effect of Posner, Calabresi, and others in extending economic analysis was to change fundamentally the formulation of legal issues in the U.S. and elsewhere. Posner's analysis shifted attention, almost exclusively, to a functional analysis of legal rules and institutions, away from the formalist, categorical analysis of legal problems prevalent before. There was, of course, an earlier history of work suggesting the importance of functional analysis of the effects of legal rules, but Posner's influence cemented the idea. In this respect, Calabresi's approach is similar. As an example, a basic tort law question prior to economic analysis was, Did X have a duty to $\mathrm{Y}$, which was typically answered either historically $-\mathrm{X}$ always has had that duty — or by a weakly defined philosophy of corrective justice $-\mathrm{X}$ should have that duty because $\mathrm{Y}$ was harmed, not $\mathrm{X}$. After the extension of economic analysis, however, the question became, What are the economic effects if $\mathrm{X}$ is found to have a duty to $\mathrm{Y}$ or the reverse, a question that can be purportedly answered by measuring costs and benefits.

However important the efficiency-of-the-law literature was to the creation of the field of law and economics, it fundamentally altered the pro-capitalist work of Director and Coase. Indeed, Posner, in many respects, is the antiCoase. The deep point of Coase's "The Problem of Social Cost" was that markets - capitalism - would overturn any legal rule that did not maximize returns for the parties affected; markets are only limited by transaction costs from doing so perfectly. ${ }^{17}$ In contrast, according to Posner, judges define economically efficient rules from the outset. As a consequence, there is no role for markets to play. Posner's judges are social engineers who define rules efficient for all circumstances. In contrast to Coase and Director, as well as to Hayek, von Mises and others, only the aggregated knowledge of the market could define the allocation of resources that maximizes social welfare.

Posner's efficiency-of-the-law theory has not exactly been successful in the sense that scholars subscribe to it. I know none who do, and even Judge Posner has privately conceded that it is an exaggeration. But the proposition had the effect of neutering Coase's advocacy

\footnotetext{
${ }^{16}$ This is made clear in a forthcoming book, Guido Calabresi, The Future of Law and Economics: Essays in Reform and Recollection, forthcoming 2012.

${ }^{17}$ Coase's radical belief in the ultimate power of markets over politics is reflected in a personal note. I was (and remain) a student of Professor Coase. After one class in the mid-1970s, I asked him "But Mr. Coase, surely the President of the United States has influence (meaning influence deriving from politics, not the market)?" He responded, "The influence of the President of the United States is \$200,000 (then, the salary of the President)."
} 
of the market order - the capitalist order-over all forms of government regulation.

\section{Capitalism in Legal Education Today}

Today, in legal education, there is little attention to capitalism as an institution or as a mechanism of social ordering. The subject is not taught. ${ }^{18}$ As mentioned, law school curricula are replete with courses addressing the legal rules that form the foundation of our capitalist order, but these courses are taught as sets of operational rules, disembodied from the operation of capitalism as an institution.

Perhaps as, in the foreseeable future, the role of government around the world must decline because of past excesses and future excess promises, legal education may focus on the dynamics of an economy, including the determinants of innovation and economic growth. If so, it will require an understanding of capitalism as an institution. There are few sensible legal scholars who deny the importance of the clear definition of property rights and contractual rights as well as the importance of tort and criminal law (though there are many debates in each of these areas over the details of the law). These legal fields are the basis of our capitalist order and, at some point, they will be acknowledged and respected for serving that role.

George L. Priest is the Edward J. Phelps Professor of Law and Economics and Kauffman Distinguished Research Scholar in Law, Economics and Entrepreneurship at Yale Law School. This article was written for a conference co-sponsored by the Manhattan Institute and Society. Grateful acknowledgement is given to the Marilyn G. Fedak Capitalism Project for its support. The author is also grateful for support from the Program in Capitalism at Yale Law School.

\footnotetext{
${ }^{18}$ Over the past 20 years at various times, I have taught with my colleague, Owen Fiss, a seminar entitled "Capitalism or Democracy?"; later (when Professor Fiss was on leave) a course "Capitalism"; and, more recently, a course "Capitalism Film Society" addressing the treatment of capitalism in films. I know of no other similar courses in any law school.
} 